\title{
Susceptibility of Selected Ericaceous Ornamental Host Species to Phytophthora ramorum
}

\author{
P. W. Tooley, USDA-ARS, Foreign Disease-Weed Science Research Unit, 1301 Ditto Ave., Ft. Detrick, MD 21702; \\ and K. L. Kyde and L. Englander, Department of Plant Sciences, University of Rhode Island, Kingston 02881
}

\begin{abstract}
Tooley, P. W., Kyde, K. L., and Englander, L. 2004. Susceptibility of selected ericaceous ornamental host species to Phytophthora ramorum. Plant Dis. 88:993-999.

We assessed disease reactions of 51 species or varieties of ericaceous ornamental hosts to two isolates of Phytophthora ramorum, the causal agent of sudden oak death. Inoculation was performed with an A2 mating type U.S. isolate from rhododendron and the P. ramorum type culture of A1 mating type from Germany. For only one host were statistically significant differences in disease observed between the two isolates. Several different inoculation methods were compared. The 51 hosts tested varied widely in susceptibility, ranging from $0 \%$ to over $90 \%$ leaf area infected. Two cultivars of Vaccinium macrocarpon (cranberry) showed no disease, while three cultivars of Kalmia latifolia (mountain laurel) were all highly susceptible. The results indicate that many ornamental hosts grown in the United States are susceptible to P. ramorum under artificial inoculation conditions. Inoculum density studies with two susceptible host species showed that $P$. ramorum is capable of producing disease symptoms over sporangium concentrations ranging from 100 to 5,000 sporangia per ml. Mean numbers of chlamydospores forming in host tissue of 21 hosts ranged from 2 to over 900 chlamydospores per 6-mm-diameter leaf disk. Whether hosts showing susceptiblity under the experimental conditions used in this study would become infected with $P$. ramorum in the presence of inoculum under natural conditions is unknown.
\end{abstract}

Additional keywords: chlamydospore, host range, inoculum density, sudden oak death

Phytophthora ramorum (S. Werres, A.W.A.M. de Cock \& W.A. Man in't Veld) sp. nov. causes sudden oak death (SOD), which is a canker disease of certain oak species that has killed thousands of trees in California since $1995(13,28)$ and has moved northward into southwestern Oregon (17). In Europe, P. ramorum is described by Werres et al. (34) as causing a dieback of Rhododendron and Viburnum spp. but since its initial characterization in Europe, researchers have considered it to be the same pathogen species as that causing oak mortality in California (28). The ever-widening host range of $P$. ramorum contains 28 species in 13 plant families

Corresponding author: P. W. Tooley

E-mail: ptooley@fdwsr.ars.usda.gov

The use of trade, firm, or corporation names in this publication (or page) is for the information and convenience of the reader. Such use does not constitute an official endorsement or approval by the United States Department of Agriculture or the Agricultural Research Service of any product or service to the exclusion of others that may be suitable.

Accepted for publication 30 April 2004.

Publication no. D-2004-0617-01R

This article is in the public domain and not copyrightable. It may be freely reprinted with customary crediting of the source. The American Phytopathological Society, 2004.
$(13,21,26)$, including two highly valued forest species, Douglas-fir and coast redwood $(11,24)$. On most reported ornamental hosts, $P$. ramorum causes foliar leaf spot or dieback symptoms in contrast to the bleeding cankers seen on trunks and limbs of its major hosts, tanoak (Lithocarpus densiflorus) and coast live oak (Quercus agrifolia) in California (13).

Although pathogens from the United States and Europe are considered to be $P$. ramorum, some important genetic differences between the subpopulations, such as mating type, have been noted $(3,18,33)$. Since its initial description from the Netherlands and Germany (34), P. ramorum has been reported from several additional European countries $(14,19,23,25)$, causing much concern and resulting in the establishment of European regulatory measures (1).

In the United States, vast amounts of plant material, including many $P$. ramorum hosts, are shipped from west to east within the nursery industry (15). Concern about movement of $P$. ramorum eastward on ornamentals or other plant-related materials, such as wood products and bay laurel wreaths, led to the establishment in 2001 of state and federal regulations restricting movement of $P$. ramorum hosts out of infested areas of California $(5,6,27)$. In 2003, new reports of $P$. ramorum infecting nursery crops were issued from Oregon, Washington, and Canada, as well as from regions of California not then under quar- antine (18,26; J. Jones, personal communication).

In March 2004, P. ramorum was identified on camellias at a nationwide nursery supplier in California, which had over the previous year, shipped potentially infected material to numerous garden centers in 39 states (32). In response, numerous states very quickly banned imports of plant material from California consisting of hosts and associated hosts of $P$. ramorum, or in some cases, all plant material. On April 9, 2004, the USDA Animal and Plant Health Inspection Agency (APHIS) implemented new restrictions on interstate movement of hosts and associated articles from all commercial nurseries in California, outside the 12 quarantined counties as well. Laboratory-confirmed positive $P$. ramorum samples were identified from nursery stock in Florida, Georgia, Louisiana, and Virginia, in addition to Oregon and Washington State (J. Jones, personal communication). These findings have alarmed growers, state regulators, foresters, and others concerned about the well-being of landscape plants and oak forests in the United States and resulted in new survey efforts directed at determining whether $P$. ramorum is now present in additional states. Knowledge of the reaction to $P$. ramorum of common ericaceous plant species grown or planted in the United States will provide information about the likelihood of various hosts to become infected and potentially contribute to new outbreaks of SOD. Information on symptomatology and susceptibility will assist in state or federal surveys that attempt to identify the pathogen in new regions.

The plant family Ericaceae contains over 100 genera and over 3,350 taxa (4), including many that are important in the nursery trade. The genus Rhododendron alone comprises over 1,000 species with several thousand varieties in existence that show adaptation to various environmental zones throughout the United States $(9,10,30)$. However, zones are not exclusive, varieties grown in the Pacific Northwest, for example, may also be grown in New England states. Other ericaceous hosts, such as mountain laurel (Kalmia latifolia), are native to the eastern United States and are also grown in the west.

Since SOD is a relatively new disease, methods for screening such diverse hosts for susceptibility are not well established $(28,29)$. Our primary objectives were to 
develop a screening method for determining susceptibility of ericaceous ornamental hosts to $P$. ramorum, and evaluate the reactions of ericaceous plant species or cultivars important in the nursery industry in the United States. As part of developing a screening method, our objective was to examine the range of inoculum density over which $P$. ramorum can infect susceptible ericaceous host species. Another objective was to evaluate the propensity of $P$. ramorum to sporulate on ericaceous hosts, thereby quantifying the ability of specific hosts to produce inoculum that might spread the disease. Our results provide information that can help predict which eastern host species may support growth of $P$. ramorum and provide inoculum for new outbreaks of the disease to occur.

\section{MATERIALS AND METHODS}

Host plants. Material was obtained from cooperators in Rhode Island, Oregon, and elsewhere (see acknowledgements) and purchased commercially. Species and cultivars were chosen to represent the diversity within the family Ericaceae while focusing on hosts of commercial importance (Table 1). Within Rhododendron, a very large genus, we included members of the major groups of deciduous and evergreen azaleas, lepidote and elepidote rhododendrons, and species representing varied geographic origins of members of the genus. Plants were maintained in a greenhouse and fertilized periodically with nutricote controlled release fertilizer, type 360/70 (Florikan, Sarasota, FL). Miracid Professional (21-7-7 formulation; ScottsSierra Horticultural Products Co., Marysville, $\mathrm{OH}$ ) was applied to rhododendrons and azaleas in the spring. Plants were transported by van to a Biosafety Level 3 containment facility where experiments were performed. Inside the containment facility, plants were maintained in a con- tainment greenhouse with an automatic drip watering system set for $5 \mathrm{~min}$ of watering two times per day on every third day.

Cultures and inoculation methods. Cultures of $P$. ramorum were obtained from cooperators in California and Germany (see acknowledgements) and maintained on Rye A (7) and 20\% V8 juice agar at 18 to $20^{\circ} \mathrm{C}$ in darkness. The two isolates used were BBA 9/95 (mating type A1, isolated in 1995 from Germany, host Rhododendron catawbiense, $P$. ramorum type culture) and Pr-52 (mating type A2, isolated in 2000 from Felton, California, host Rhododendron cv. 'Gomer Waterer'), which have been described in previous studies $(28,34)$.

$P$. ramorum sporangia were produced by cutting 10 to 15 6-mm-diameter plugs from the margin of a 10- to 14-day-old V8 agar culture with a cork borer and placing them into $20 \mathrm{ml}$ of $1 \%$ soil extract (made

Table 1. Unadjusted and adjusted percentage leaf area infected as measures of susceptibility of 51 ericaceous plant hosts inoculated with two isolates of Phytophthora ramorum ${ }^{\mathrm{a}}$

\begin{tabular}{|c|c|c|c|c|c|c|c|}
\hline \multirow[b]{3}{*}{ Host } & \multirow[b]{3}{*}{ Common name and origin or parentage } & \multicolumn{3}{|c|}{ Unadjusted \% leaf area infected } & \multicolumn{3}{|c|}{ Adjusted \% leaf area infected ${ }^{b}$} \\
\hline & & \multicolumn{3}{|c|}{ Isolate } & \multicolumn{3}{|c|}{ Isolate } \\
\hline & & BBA 9/95 & Pr-52 & Mean $^{\text {d }}$ & BBA 9/95 & Pr-52 & Mean $^{\text {d }}$ \\
\hline Arctostaphylos uva-ursi & Bearberry; NE U.S. native & 38.9 & 47.2 & 43.0 & 15.5 & 27.2 & 21.4 \\
\hline Gaultheria procumbens & Wintergreen; E U.S. native & 6.4 & 5.9 & 6.1 & 1.9 & 2.3 & 2.1 \\
\hline Gaylussacia baccata & Black huckleberry; E U.S. native & 22.9 & 12.1 & 17.5 & 7.3 & 2.6 & 4.9 \\
\hline Gaylussacia frondosa & Blue huckleberry; E. U.S. native & 11.7 & 27.7 & 19.7 & 7.7 & 13.3 & 10.5 \\
\hline Kalmia angustifolia & Sheep laurel; NE U.S. native & 5.4 & 1.9 & 3.6 & 0.8 & 0.5 & 0.6 \\
\hline K. latifolia 'Madeline' & Mountain laurel; cv. of U.S. native & 59.0 & 67.7 & 63.3 & 49.6 & 66.1 & 57.9 \\
\hline K. latifolia 'Minuet' & Mountain laurel; cv. of U.S. native & 96.2 & 93.3 & 94.8 & 96.2 & 88.1 & 92.1 \\
\hline $\begin{array}{l}\text { K. latifolia } \\
\text { 'Olympic Wedding' }\end{array}$ & Mountain laurel; cv. of U.S. native & 71.3 & 27.1 & 49.2 & 70.4 & 22.5 & 46.5 \\
\hline $\begin{array}{l}\text { Leucothoe axillaris } \\
\text { 'Greensprite' }\end{array}$ & $\begin{array}{l}\text { Greensprite doghobble; } \\
\text { cV. of SE U.S. native }\end{array}$ & 3.2 & 4.6 & 3.9 & 0.1 & 1.0 & 0.6 \\
\hline L. fontanesiana & $\begin{array}{l}\text { Highland doghobble; Massachusetts, } \\
\text { New York, and SE U.S. native }\end{array}$ & 4.7 & 1.4 & 3.0 & 2.2 & 0.5 & 1.4 \\
\hline Pieris floribunda & Mountain fetterbush; SE U.S. native & 9.5 & 10.9 & 10.2 & 3.8 & 4.7 & 4.2 \\
\hline P. japonica & Japanese pieris; Japan & 5.8 & 33.7 & 19.7 & 1.7 & 26.9 & 14.3 \\
\hline Rhododendron 'Aglo' & $\begin{array}{l}\text { Aglo rhododendron; } R \text {. minus, } \\
\text { compact form } \times R \text {. dauricum hybrid }\end{array}$ & 30.5 & 20.4 & 25.5 & 17.5 & 9.8 & 13.6 \\
\hline R. arborescens & Smooth azalea; E U.S. native & 9.4 & 8.8 & 9.1 & 2.6 & 1.5 & 2.1 \\
\hline R. calendulaceum & Flame azalea; E North American native & 28.9 & 28.6 & 28.8 & 12.5 & 10.7 & 11.6 \\
\hline R. carolinianum & $\begin{array}{l}\text { Carolina azalea; Tennessee, North Carolina, } \\
\text { South Carolina, and Connecticut native }\end{array}$ & 10.8 & 8.5 & 9.6 & 3.8 & 2.1 & 3.0 \\
\hline R. catawbiense & Catawba rhododendron; E U.S.native & 18.2 & 8.2 & 13.2 & 8.4 & 3.0 & 5.7 \\
\hline Rhododendron 'Chinoides' & Chinoides rhododendron; $R$. ponticum hybrid & 11.6 & 25.4 & 18.5 & 3.4 & 13.1 & 8.2 \\
\hline $\begin{array}{l}\text { Rhododendron } \\
\text { 'Cunningham's White' }\end{array}$ & $\begin{array}{l}\text { Cunningham's White rhododendron; } \\
R \text {. caucasicum } \times \text { ponticum var. album }\end{array}$ & 48.7 & 27.8 & 38.3 & 42.0 & 22.7 & 32.4 \\
\hline R. dauricum PJM type & Seedling of Siberian species & 24.8 & 28.3 & 26.5 & 7.4 & 11.8 & 9.6 \\
\hline $\begin{array}{l}\text { Rhododendron } \\
\text { 'Delaware Valley White' }\end{array}$ & $\begin{array}{l}\text { Delaware Valley White azalea; } \\
\text { R. mucronatum hybrid }\end{array}$ & 20.9 & 27.3 & 24.1 & 13.4 & 10.2 & 11.8 \\
\hline $\begin{array}{l}\text { Rhododendron } \\
\text { 'Exbury hybrid' }\end{array}$ & $\begin{array}{l}\text { Exbury hybrid rhododendron; } \\
\text { parentage unknown }\end{array}$ & 9.1 & 10.7 & 9.9 & 7.5 & 6.4 & 6.9 \\
\hline $\begin{array}{l}\text { Rhododendron } \\
\text { 'Girard's Fuchsia' }\end{array}$ & $\begin{array}{l}\text { Girard's Fuchsia azalea; } \\
\text { ('Sandra Ann' × ['Herbert' × 'Girard's Hot } \\
\text { Shot']) ×`Sandra Ann' }\end{array}$ & 22.8 & 13.6 & 18.2 & 2.7 & 1.6 & 2.2 \\
\hline $\begin{array}{l}\text { Rhododendron } \\
\text { 'Girard's Rose' }\end{array}$ & $\begin{array}{l}\text { Girard's Rose azalea; (['Fedora' } \times \\
\text { 'El Capitan'] } \times \text { ['Boudoir'] × 'Boudoir') }\end{array}$ & 5.0 & 14.5 & 9.7 & 1.1 & 1.0 & 1.0 \\
\hline
\end{tabular}

${ }^{a}$ Intact leaves on whole host plants were dip inoculated with a suspension of 5,000 sporangia per $\mathrm{ml}$ of $P$. ramorum and incubated in a dew chamber at $20^{\circ} \mathrm{C}$ in darkness for 7 days.

${ }^{\mathrm{b}}$ Mean percent leaf area infected multiplied by the proportion of leaves becoming infected in each set of 25 inoculated leaves.

${ }^{\mathrm{c}} \mathrm{cv} .=$ cultivar, $\mathrm{E}=$ eastern, $\mathrm{N}=$ northern, $\mathrm{NE}=$ northeastern, $\mathrm{SC}=$ southcentral, and $\mathrm{SE}=$ southeastern.

${ }^{\mathrm{d}}$ Overall mean for each host over the two isolates used for inoculation.

${ }^{\mathrm{e}}$ Minimum significant difference (MSD) for comparing interaction means (i.e., host $\times$ isolate means), Tukey's studentized range test $(P=0.05)$.

${ }^{\mathrm{f}}$ Minimum significant difference (MSD) for comparing main effects means (i.e., means over both isolates), Tukey's studentized range test $(P=0.05)$. 
by autoclaving $10 \mathrm{~g}$ of garden soil in $1 \mathrm{~L}$ of distilled water, vacuum-filtering through Whatman no. 1 filter paper, and then reautoclaving) in 9-cm-diameter petri dishes for $48 \mathrm{~h}$ at $20^{\circ} \mathrm{C}$ in darkness. Sporangia formed in abundance on and around each agar plug and were collected by applying Parafilm to the petri dish perimeters, vigorously shaking them horizontally for 10 sec to dislodge sporangia, and then pouring through four layers of cheesecloth to remove mycelial fragments. Sporangia suspensions were quantified with a hemacytometer and by counting the number of sporangia present in several $5-\mu l$ drops sampled randomly from the suspension, and adjusted to 5,000 sporangia per $\mathrm{ml}$. When counts below 5,000 per $\mathrm{ml}$ were obtained, spores were concentrated by centrifugation at $254 \times g$ in a tabletop centrifuge for $5 \mathrm{~min}$ at $15^{\circ} \mathrm{C}$.

To develop a screening method for $P$. ramorum, we experimented with several different types of inoculation. Mycelial suspension was produced by removing a
2.5- $\mathrm{cm}^{2}$ area of hyphae from the surface of a $20 \%$ V8 juice agar culture to a depth of approximately $2 \mathrm{~mm}$ with a scalpel and grinding in a glass tissue grinder with 10 $\mathrm{ml}$ of sterile distilled water until finely macerated. Plant wounding was performed by cutting off the terminal $3 \mathrm{~mm}$ of leaf tissue with a scissors.

Dipping plants in a mycelial suspension was compared with dipping in a sporangia suspension. Plants were inoculated by dipping limbs (or when plants contained less than 25 leaves, the entire plants) containing groups of at least 25 leaves into a sporangia suspension $(5,000$ per $\mathrm{ml})$ or mycelial suspension in gallon-size plastic zip-lock bags. The foliage was immersed completely to ensure saturation with inoculum, agitated gently in the inoculum, and then gently shaken before removal from the bags to remove excess inoculum. To prevent drying of inoculum on the leaves, plants were placed immediately into a $20^{\circ} \mathrm{C}$ dew chamber and incubated for 7 days in darkness. Following symptom development, isolation attempts were made from lesion margins onto PARP selective medium (20).

For each host/isolate combination in all experiments, four sets of at least 25 leaves were inoculated and when possible, all four sets chosen were located on the same plant. After 7 days of incubation in the dew chamber at $20^{\circ} \mathrm{C}$ in the dark, the areas of leaves and $P$. ramorum lesions were measured. For each set of at least 25 leaves that were inoculated with a given isolate, 25 leaves were chosen randomly and assessed for disease symptoms. To assess disease in initial studies, leaf outlines were traced with a pencil onto white paper. With the leaf held in place, a pencil point was pressed through the leaf at points 2 to 3 $\mathrm{mm}$ apart along the lesion margins, making dots on the paper. The leaf was then removed, and the dots were connected, displaying the lesion shape within the already traced leaf shape. Leaf and lesion areas were then measured $\left(\mathrm{cm}^{2}\right)$ with a handheld digital planimeter (model KP-82N;

Table 1. (continued from preceding page)

\begin{tabular}{|c|c|c|c|c|c|c|c|}
\hline \multirow[b]{3}{*}{ Host } & \multirow[b]{3}{*}{ Common name and origin or parentage $\mathrm{c}^{\mathrm{c}}$} & \multicolumn{3}{|c|}{ Unadjusted \% leaf area infected } & \multicolumn{3}{|c|}{ Adjusted \% leaf area infected ${ }^{b}$} \\
\hline & & \multicolumn{3}{|c|}{ Isolate } & \multicolumn{3}{|c|}{ Isolate } \\
\hline & & BBA 9/95 & Pr-52 & Mean $^{\text {d }}$ & BBA 9/95 & Pr-52 & Mean $^{d}$ \\
\hline Rhododendron 'Glacier' & $\begin{array}{l}\text { Glacier azalea; Glenn Dale hybrid } \\
\text { 'Malvatica' × 'Yozakura' }\end{array}$ & 9.1 & 29.1 & 19.1 & 1.0 & 3.6 & 2.3 \\
\hline Rhododendron 'Gloria' & Gloria azalea; sport of 'Dorothy Gish' & 18.0 & 13.2 & 15.6 & 1.5 & 2.4 & 1.9 \\
\hline $\begin{array}{l}\text { Rhododendron } \\
\text { 'Hino Crimson' }\end{array}$ & $\begin{array}{l}\text { Hino Crimson azalea; } \\
\text { 'Amoenum’ } \times \text { ‘HinodeGiri' }\end{array}$ & 0.8 & 0 & 0.4 & 0 & 0 & 0 \\
\hline R. indicum 'Macrantha' & Macrantha azalea; Japan & 11.3 & 5.3 & 8.3 & 1.5 & 0.4 & 0.9 \\
\hline Rhododendron 'Inga' & Inga azalea; sport of 'Helmut Vogel' & 5.9 & 19.2 & 12.6 & 1.2 & 2.0 & 1.6 \\
\hline R. macrosepalum & Big sepal azalea; S Japan & 3.8 & 1.8 & 2.8 & 0.3 & 0.2 & 0.2 \\
\hline Rhododendron 'Marilee' & $\begin{array}{l}\text { Marilee azalea; } \\
\text { cv. from open-pollinated } R . \text { nakaharai }\end{array}$ & 7.9 & 16.3 & 12.1 & 1.3 & 2.4 & 1.9 \\
\hline R. maximum & Rosebay rhododendron; E U.S. native & 5.6 & 3.7 & 4.7 & 3.0 & 1.5 & 2.2 \\
\hline R. micranthum & $\mathrm{N}$ China native & 36.1 & 21.7 & 28.9 & 19.5 & 7.3 & 13.4 \\
\hline R. minus & Piedmont rhododendron; SE U.S. native & 9.4 & 8.8 & 9.1 & 3.6 & 3.0 & 3.3 \\
\hline $\begin{array}{l}\text { Rhododendron } \\
\text { 'Nova Zembla' }\end{array}$ & $\begin{array}{l}\text { Nova Zembla rhododendron; } \\
\text { 'Parson's grandiflorum' } \times \text { 'Mars' }\end{array}$ & 34.4 & 54.1 & 44.3 & 26.9 & 40.2 & 33.6 \\
\hline Rhododendron 'PJM' & $\begin{array}{l}\text { PJM rhododendron; } R \text {. carolinianum } \times \\
R \text {. dauricum var. sempervirens }\end{array}$ & 8.9 & 5.9 & 7.4 & 1.6 & 0.3 & 0.9 \\
\hline $\begin{array}{l}\text { Rhododendron } \\
\text { 'Purple Gem' }\end{array}$ & $\begin{array}{l}\text { Purple Gem azalea; } \\
\quad \text { R. fastigiatum } \times \text { carolinianum }\end{array}$ & 43.6 & 41.1 & 42.3 & 10.7 & 6.1 & 8.4 \\
\hline $\begin{array}{l}\text { Rhododendron } \\
\text { 'Purple Splendor' }\end{array}$ & $\begin{array}{l}\text { Purple Splendor azalea; Gable hybrid } \\
\text { (R. poukhanense } \times \text { 'Hexe') }\end{array}$ & 3.5 & 0.1 & 1.8 & 0.4 & 0 & 0.2 \\
\hline $\begin{array}{l}\text { Rhododendron } \\
\text { 'Roseum Elegans' }\end{array}$ & $\begin{array}{l}\text { Roseum elegans rhododendron } \\
\text { R. catawbiense hybrid }\end{array}$ & 20.4 & 10.5 & 15.4 & 10.9 & 5.7 & 8.3 \\
\hline R. vaseyi & Pinkshell azalea; U.S. native & 30.5 & 14.1 & 22.3 & 28.8 & 13.6 & 21.1 \\
\hline R. viscosum & Swamp azalea; E and SC U.S. native & 7.1 & 1.9 & 4.5 & 1.4 & 1.1 & 1.3 \\
\hline $\begin{array}{l}\text { R. yakushimanum } \\
\text { 'Ken Janeck' }\end{array}$ & $\begin{array}{l}\text { Ken Janeck rhododendron; } \\
\text { seedling of S Japan species }\end{array}$ & 6.4 & 4.0 & 5.2 & 3.1 & 0.5 & 1.8 \\
\hline $\begin{array}{l}\text { R. yedoense } \\
\text { var. poukhanense }\end{array}$ & Korean azalea; Korea, Japan & 6.9 & 4.7 & 5.8 & 4.3 & 1.6 & 3.0 \\
\hline Umbellularia californica & California bay laurel; U.S. native & 21.3 & 28.3 & 24.8 & 20.8 & 25.0 & 22.9 \\
\hline Vaccinium angustifolium & Lowbush blueberry; NE and NC U.S. native & 8.8 & 8.3 & 8.6 & 2.9 & 4.1 & 3.5 \\
\hline V. corymbosum 'Bluecrop' & $\begin{array}{l}\text { Highbush blueberry; commercial cv. } \\
\text { of E and SC U.S. native }\end{array}$ & 0.9 & 1.6 & 1.2 & 0.5 & 1.0 & 0.7 \\
\hline V. corymbosum 'Duke' & $\begin{array}{l}\text { Highbush blueberry; } \\
\text { commercial cv. of E and SC U.S. native }\end{array}$ & 1.8 & 1.4 & 1.6 & 0.3 & 0.4 & 0.4 \\
\hline $\begin{array}{l}\text { V. corymbosum } \\
\text { 'Weymouth' }\end{array}$ & $\begin{array}{l}\text { Highbush blueberry; } \\
\text { commercial cv. of E and SE U.S. native }\end{array}$ & 2.2 & 2.8 & 2.5 & 1.3 & 2.7 & 2.0 \\
\hline V. macrocarpon 'Crowley' & Cranberry; commercial cv. of U.S. native & 0 & 0 & 0 & 0 & 0 & 0 \\
\hline V. macrocarpon 'Stevens' & Cranberry; commercial cv. of U.S. native & 0 & 0 & 0 & 0 & 0 & 0 \\
\hline Zenobia pulverulenta & Honeycup; SE U.S. native & 2.7 & 1.8 & 2.2 & 0.4 & 0.3 & 0.3 \\
\hline $\begin{array}{l}\text { Overall mean } \\
\text { MSD value (Tukey's test, } P\end{array}$ & $=0.05)$ & 17.3 & $\begin{array}{l}16.8 \\
28.8^{\mathrm{e}}\end{array}$ & $18.9^{\mathrm{f}}$ & 10.3 & $\begin{array}{c}9.3 \\
22.6^{\mathrm{e}}\end{array}$ & $14.8^{\mathrm{f}}$ \\
\hline
\end{tabular}


Topcon, Inc., Pleasanton, CA). To expedite the measuring process, midway through these studies we adopted the use of ASSESS (22) software to measure leaf and lesion areas by placing infected leaves on a flatbed scanner, scanning them, and saving the scans as JPEG files. Files were then opened in ASSESS and hue and intensity settings were adjusted to highlight and measure $\left(\mathrm{cm}^{2}\right)$ leaf and lesion areas. The two methods of measuring leaf and lesion areas were compared statistically (31) by measuring a set of 35 infected leaves of Pieris floribunda with both methods and no significant differences $(P=0.05)$ were observed.

Disease was expressed as percent leaf area infected. In initial studies, the number of leaves infected by $P$. ramorum out of randomly chosen groups of 25 leaves of several hosts was analyzed by analysis of variance (ANOVA) and was found to differ significantly. Thus, we determined that the number of leaves infected would serve as an additional measure of resistance or susceptibility to $P$. ramorum. To produce a measure of resistance/susceptibility that incorporated the number of leaves becoming infected along with the percent leaf area infected for leaves that did become infected, we calculated an adjusted percent leaf area infected by multiplying the mean percent leaf area infected for each set of 25 inoculated leaves by the proportion of the 25 leaves that had become infected for each set. Unadjusted and adjusted percent leaf area was analyzed using ANOVA within the GLM procedure in SAS (31).

Inoculum density studies. Seven sets of 25 randomly preselected leaves on whole plants of bearberry (Arctostaphylos uva-ursi) and 'Minuet' mountain laurel ( $K$. latifolia 'Minuet') were inoculated with sporangia suspensions containing 0,50 , $100,500,1,000,2,000,3,000,4,000$, or 5,000 sporangia per $\mathrm{ml}$ of $P$. ramorum isolate Pr-52. Inoculated plants were incubated in a dew chamber at $20^{\circ} \mathrm{C}$ for 7 days in darkness after which lesion and leaf areas were measured with ASSESS software as described above. The total lesion area produced by $P$. ramorum for each set of 25 inoculated leaves at each inoculum level was calculated and plotted against inoculum concentration. The data were subjected to regression analysis and analysis of covariance using PROC GLM in SAS (31).

Chlamydospore production. Leaf disks (6 $\mathrm{mm}$ in diameter) were removed with a paper punch and immersed in $5 \mathrm{ml}$ of a $P$. ramorum sporangia suspension $(5,000$ sporangia per $\mathrm{ml}$ in $1 \%$ of soil extract) in 6-cm-diameter petri dishes for 48 $\mathrm{h}$ at $20^{\circ} \mathrm{C}$ in darkness. The disks were then rinsed with several changes of sterile distilled water and incubated in a submerged fashion in $5 \mathrm{ml}$ of sterile distilled water for an additional 12 days at $20^{\circ} \mathrm{C}$ in darkness. The number of chlamydospores in the leaf tissue (abaxial and adaxial leaf surfaces) was then counted under a dissecting microscope with grids etched onto 6-mmdiameter clear acetate circles to facilitate counting. Only chlamydospores observable in the first few layers of plant cells on upper and lower leaf disk surfaces were counted and it was determined with a scalpel that disks were thick enough to prevent the seeing "through" of the leaf section and counting some chlamydospores twice. An inoculating loop was passed over the surface of each leaf disk prior to counting to scrape away any chlamydospores formed superficially on the disks or intertwined in superficial hyphae and not in the plant tissue. Three sets of eight leaf disks were inoculated and assessed per host/isolate combination, with Rhododendron 'Cunningham's White' leaf disks included in each set as a positive control.

\section{RESULTS}

Inoculation methods. Inoculation of tissue (wounded or nonwounded) with $P$. ramorum sporangia was compared with inoculation (wounded) with a suspension of mycelium (Table 2). Significant differences were observed in unadjusted and adjusted percent leaf area infected among five azalea varieties tested, 'Gloria' and 'Girard's Fuchsia' were the most susceptible and 'Inga' and 'Purple Splendor' were the least susceptible (Table 2). Inoculation treatments differed significantly for percent leaf area infected and adjusted percent leaf area infected, with the mycelium/wounding method causing the most disease over all the azaleas tested, followed by the two sporangial inoculation methods (wounding versus nonwounding) which did not differ significantly from one another. A marginally significant host $x$ treatment interaction was observed $(P=$ 0.0759 ) for percent leaf area infected and adjusted percent leaf area infected. Since the sporangia nonwounding method resulted in the same degree of overall infection as did the sporangia wounding method, we chose to use the nonwounding method in further studies. Even though more disease was produced with mycelial suspension as inoculum, we chose to use sporangia in further studies because they represent a natural form of inoculum.

Plant inoculations. In addition to the five azaleas initially screened, we screened 46 additional hosts with the sporangia, nonwounding method. These hosts varied widely in their reaction to inoculation with two isolates of $P$. ramorum (Table 1). Symptomatology varied among hosts, with most disease reactions characterized by the presence of spreading brown or black lesions which occurred randomly over the leaf surface area (2). Dieback symptoms were occasionally observed in that lesions were present on petioles and stems; however, we did not attempt to quantify dieback symptoms. Unadjusted percentage leaf area infected varied from above $95 \%$ for K. latifolia 'Minuet' (mountain laurel) to $0 \%$ for Vaccinium macrocarpon (cranberry). The most susceptible hosts for

Table 2. Comparison of three different types of inoculation of five different azaleas with isolate BBA 9/95 of Phytophthora ramorum ${ }^{\mathrm{a}}$

\begin{tabular}{|c|c|c|c|c|c|c|c|c|}
\hline \multirow[b]{3}{*}{ Host } & \multicolumn{4}{|c|}{ Unadjusted \% leaf area infected } & \multicolumn{4}{|c|}{ Adjusted $\%$ leaf area infected ${ }^{b}$} \\
\hline & \multicolumn{4}{|c|}{ Method of inoculation } & \multicolumn{4}{|c|}{ Method of inoculation } \\
\hline & $\begin{array}{c}\text { Mycelium } \\
\text { wound }\end{array}$ & $\begin{array}{l}\text { Sporangia } \\
\text { wound }\end{array}$ & $\begin{array}{l}\text { Sporangia } \\
\text { nonwound }\end{array}$ & $\begin{array}{c}\text { Overall } \\
\text { mean }^{\mathrm{c}}\end{array}$ & $\begin{array}{c}\text { Mycelium } \\
\text { wound }\end{array}$ & $\begin{array}{l}\text { Sporangia } \\
\text { wound }\end{array}$ & $\begin{array}{l}\text { Sporangia } \\
\text { nonwound }\end{array}$ & $\begin{array}{c}\text { Overall } \\
\text { mean }^{\mathrm{c}}\end{array}$ \\
\hline 'Girard's Fuchsia' & 25.5 & 12.5 & 22.8 & 20.2 & 8.5 & 1.6 & 2.7 & 4.3 \\
\hline 'Glacier' & 15.4 & 15.4 & 9.1 & 13.3 & 3.2 & 5.2 & 1.0 & 3.1 \\
\hline 'Gloria' & 31.7 & 23.3 & 18.0 & 24.3 & 4.7 & 6.1 & 1.5 & 4.1 \\
\hline 'Inga' & 8.1 & 2.2 & 5.9 & 5.4 & 1.0 & 0.3 & 1.2 & 0.8 \\
\hline 'Purple Splendor' & 13.6 & 5.5 & 3.5 & 7.5 & 1.1 & 0.7 & 0.4 & 0.7 \\
\hline Overall & 18.8 & 11.8 & 11.9 & $6.6^{\mathrm{d}}$ & 3.7 & 2.8 & 1.4 & $2.3^{\mathrm{d}}$ \\
\hline MSD value & & $21.9^{\mathrm{e}}$ & & $10.0^{\mathrm{f}}$ & & $7.5^{\mathrm{e}}$ & & $3.4^{\mathrm{f}}$ \\
\hline
\end{tabular}

${ }^{a}$ Leaves were dip inoculated with a mycelial suspension or with 5,000 sporangia per $\mathrm{ml}$ of $P$. ramorum isolate BBA $9 / 95$ and incubated in a dew chamber at

$20^{\circ} \mathrm{C}$ in darkness for 7 days. Wounding was achieved by cutting off the last $3 \mathrm{~mm}$ of the leaf with scissors.

${ }^{\mathrm{b}}$ Mean percent leaf area infected multiplied by the proportion of leaves becoming infected in each set of 25 inoculated leaves.

${ }^{c}$ Overall mean for the three different inoculation methods.

${ }^{\mathrm{d}}$ Minimum significant difference (MSD) value for comparing main effects of inoculation treatments over all cultivars, Tukey's studentized range (HSD) test $(P=0.05)$.

${ }^{\mathrm{e}}$ Minimum significant difference for comparing interaction means, Tukey's studentized range (HSD) test $(P=0.05)$.

${ }^{\mathrm{f}}$ Minimum significant difference for comparing main effects means, Tukey's studentized range (HSD) test $(P=0.05)$. 
unadjusted percent leaf area infected included three $K$. latifolia cultivars, 'Cunningham's White' rhododendron, other Rhododendron species, and bearberry ( $A$. uva-ursi) (Table 1). In contrast, the least susceptible hosts included cranberry and highbush blueberry (Table 1). While the native species, $K$. latifolia, was highly susceptible to $P$. ramorum, its relative, $K$. angustifolia (sheep laurel), was among the



Fig. 1. Responses of Minuet mountain laurel (Kalmia latifolia 'Minuet') and bearberry (Arctostaphylos uva-ursi) to increasing density of Phytophthora ramorum sporangia (0 to 5,000 sporangia per $\mathrm{ml}$ ) in nonwounding, dip inoculation of intact plants followed by 7 days of incubation in a dew chamber at $20^{\circ} \mathrm{C}$ in darkness. The total amount of infected leaf area obtained at each inoculum density was plotted against inoculum density. Bars represent standard errors based on seven data points (each data point representing a group of 25 inoculated leaves) at each concentration for each host. Linear regression equations for each curve are given in the text, with adjusted $R^{2}$ values of 0.81 for both hosts. most resistant species tested with a mean adjusted percent leaf area infected value of just $0.6 \%$ (Table 1). U.S. native species of Rhododendron varied in susceptibility to $P$. ramorum, with the most susceptible being R. vaseyi $(21.1 \%$ adjusted percent leaf area infected) and the least susceptible being $R$. viscosum $(1.3 \%$ adjusted percent leaf area infected). Species of Asiatic origin also varied in susceptibility, but some were less susceptible, such as $R$. yakushimanum 'Ken Janeck' ( $1.8 \%$ adjusted percent leaf area infected) and $R$. macrosepalum $(0.2 \%$ adjusted percent leaf area infected).

For unadjusted and adjusted percent leaf area infected, significant differences $(P<$ $0.0001)$ were observed among host main effects but not isolate main effects, and a statistically significant host $\times$ isolate interaction was observed $(P<0.0001)$. When interaction means were compared using Tukey's studentized range test, a statistically significant $(P=0.05)$ difference was observed between isolates in unadjusted and adjusted percent leaf area infected for only one host ( $K$. latifolia 'Olympic Wedding') (Table 2). P. ramorum was reisolated from host lesion margins onto PARP selective medium from all hosts except those showing no characteristic disease symptoms.

Inoculum density relationships. Inoculum density studies showed that $P$. ramorum was capable of infecting bearberry and 'Minuet' mountain laurel over a wide range of inoculum levels and as low as 100 sporangia per ml (Fig. 1). No dis-

Table 3. Number of Phytophthora ramorum chlamydospores produced on leaf disks of selected ericaceous hosts

\begin{tabular}{|c|c|c|c|c|c|c|c|}
\hline \multirow[b]{3}{*}{ Host } & \multicolumn{7}{|c|}{ Number of chlamydospores per 6-mm-diameter leaf disk ${ }^{a}$} \\
\hline & \multicolumn{3}{|c|}{ Isolate BBA 9/95 } & \multicolumn{3}{|c|}{ Isolate Pr-52 } & \multirow{2}{*}{$\begin{array}{c}\text { Overall } \\
\text { mean }^{c}\end{array}$} \\
\hline & Top $^{\mathbf{b}}$ & Bottom & Total & Top $^{\mathbf{b}}$ & Bottom & Total & \\
\hline Arctostaphylos uva-ursi & 156 & 55 & 211 & 259 & 102 & 361 & 286 \\
\hline Gaultheria procumbens & 709 & 240 & 949 & 592 & 287 & 879 & 914 \\
\hline Kalmia angustifolia & 2 & 1 & 3 & 7 & 2 & 9 & 6 \\
\hline Pieris japonica & 204 & 86 & 290 & 218 & 150 & 367 & 328 \\
\hline Rhododendron arborescens & 41 & 37 & 78 & 16 & 13 & 29 & 53 \\
\hline R. carolinianum & 110 & 127 & 237 & 95 & 110 & 205 & 221 \\
\hline R. catawbiense & 64 & 72 & 136 & 59 & 145 & 204 & 170 \\
\hline Rhododendron 'Cunningham's White' & 280 & 205 & 485 & 312 & 162 & 474 & 479 \\
\hline Rhododendron 'Delaware Valley White' & 190 & 131 & 321 & 151 & 121 & 272 & 297 \\
\hline Rhododendron 'Girard's Rose' & 97 & 98 & 195 & 188 & 247 & 434 & 315 \\
\hline Rhododendron 'Gloria' & 102 & 57 & 159 & 92 & 76 & 168 & 164 \\
\hline R. maximum & 66 & 51 & 117 & 71 & 47 & 118 & 118 \\
\hline R. minus & 46 & 38 & 84 & 55 & 37 & 92 & 88 \\
\hline Rhododendron 'Roseum elegans' & 152 & 126 & 278 & 149 & 117 & 266 & 272 \\
\hline Umbellularia californica & 359 & 96 & 455 & 782 & 139 & 921 & 688 \\
\hline Vaccinium angustifolium & 3 & 1 & 4 & 8 & 6 & 14 & 9 \\
\hline V. corymbosum 'Duke' & 1 & 1 & 2 & 2 & 0 & 2 & 2 \\
\hline V. corymbosum 'Blue Crop' & 1 & 1 & 2 & 2 & 0 & 2 & 2 \\
\hline V. macrocarpon 'Crowley' & 7 & 5 & 12 & 9 & 7 & 16 & 14 \\
\hline V. macrocarpon'Stevens & 1 & 1 & 2 & 2 & 1 & 3 & 3 \\
\hline Zenobia pulverulenta & 1 & 3 & 4 & 2 & 4 & 6 & 5 \\
\hline Tukey MSD value $(P=0.05)^{\mathrm{d}}$ & 113 & 51 & 132 & 113 & 51 & 132 & 96 \\
\hline
\end{tabular}


ease was observed at 0 or 50 sporangia per $\mathrm{ml}$. Bearberry showed a significant linear slope component $(\operatorname{Pr}>F=0.0004)$ and a nonsignificant $(\operatorname{Pr}>F=0.5241)$ quadratic component. The linear regression equation describing the relationship between total lesion area $(y)$ and inoculum density $(x)$ was $y=0.422+0.00326 x$ with an adjusted $R^{2}$ value of 0.81 . Mountain laurel 'Minuet' was also found to have a significant linear slope component $(\mathrm{Pr}>F<0.0001)$ and nonsignificant quadratic component $(\mathrm{Pr}>$ $F=0.5921$ ). The linear regression equation describing the relationship between $y$ and $x$ was $y=0.1637+0.00312 x$ with an adjusted $R^{2}$ value of 0.81 .

Chlamydospore production. Mean chlamydospore numbers produced in 6mm-diameter leaf disks ranged from 914 in Gaultheria procumbens to only 2 chlamydospores produced in tissue of 'Duke' and 'Bluecrop' highbush blueberry following 12 days of incubation at $20^{\circ} \mathrm{C}$ in darkness (Table 3 ). The numbers of chlamydospores forming on upper and lower surfaces of the leaf disks were assessed and combined for the total. Significant host effects, isolate effects, and a host $\times$ isolate interaction were observed for upper surface chlamydospores produced, lower surface chlamydospores produced, and the total number of chlamydospores produced per leaf disk. Averaged over all hosts, isolate $\operatorname{Pr}-52$ produced significantly $(P=$ $0.01)$ greater numbers of chlamydospores than did isolate BBA 9/95 for upper surface, lower surface, and total chlamydospores. For both isolates, significantly $(P=0.01)$ greater numbers of chlamydospores were produced on upper leaf surfaces compared with lower leaf surfaces.

\section{DISCUSSION}

We evaluated the reactions of 51 ericaceous ornamental hosts to two isolates of $P$. ramorum and found that host species and cultivars differ widely in their reactions. After comparison of several inoculation methods, the method we adopted involved dipping host plants into a suspension of 5,000 sporangia per $\mathrm{ml}$ followed by 7 days of incubation in a dew chamber at $20^{\circ} \mathrm{C}$ in darkness. This method is advantageous because it does not require wounding of the host, which might give the pathogen an advantage and result in greater susceptibility than would occur in nature. Sporangia play a major role in dispersal of many Phytophthora species, including $P$. ramorum, in which dispersal is hypothesized to occur via windsplashing rain (12). Thus, using sporangia for inoculation seemed more natural compared with another described method of pinning agar plugs containing hyphae to leaves of host plants (28).

The conditions we used for incubation during our screening tests, 7 days at $20^{\circ} \mathrm{C}$ in darkness, are unnatural in the degree of darkness to which plants are subjected. Plants subjected to sustained darkness may be more vulnerable to pathogen infection because of their inability to photosynthesize during the incubation period and perhaps also because of physiological effects on other phenomena such as stomate opening and closing. However, in spite of these conditions, we obtained a wide range of susceptibility among the hosts tested, indicating that incubation conditions were not sufficient to overcome resistance of many hosts.

On the basis of mean adjusted percent leaf area infected, averaged over both isolates used for inoculation, cranberry $(V$. macrocarpon), 'Hino Crimson' azalea, and highbush blueberry ( $V$. corymbosum) were the most resistant hosts tested, while mountain laurel ( $K$. latifolia) and some common Rhododendron cultivars were among the most susceptible hosts tested. California bay laurel that sustained approximately $25 \%$ leaf area infected in our tests, is thought to play a significant role in providing inoculum for SOD epidemics in California, where it grows commonly as an understory tree in oak forests. Although not as susceptible in terms of percent leaf area infected compared with other susceptible hosts, we and other researchers (12) have observed leaf disks of this host to sustain very high levels of sporangia production when inoculated and placed in water or $1 \%$ soil extract. The fact that this host does not rapidly become necrotic when infected with $P$. ramorum may contribute to its ability to provide sustained spore production in the forest ecosystem.

The use of adjusted percent leaf area infected altered disease ratings for some hosts compared with unadjusted percent leaf area infected. For example, Rhododendron 'Glacier' showed a mean unadjusted percent leaf area infected of $19.1 \%$ but a mean adjusted percent leaf area infected of only $2.3 \%$, showing that the adjustment for the number of leaves of each group of 25 with lesions had a strong effect in some cases. Adjusted percent leaf area infected is likely a more accurate measure of susceptibility or resistance of a given host because it reflects the number of leaves infected as well as the severity of disease on the infected leaves.

The two isolates used for inoculation did not produce significantly different amounts of disease when averaged over all hosts, even though a statistically significant host $x$ isolate interaction was observed. However, for only one host ( $K$. latifolia 'Olympic Wedding') was a statistically significant difference observed between isolates for unadjusted and adjusted percent leaf area infected. Thus, in most cases, hosts responded similarly to the two isolates used. This may be surprising given that the two isolates represented genetic extremes within $P$. ramorum. Isolate BBA9/95 originated from $R$. catawbiense in Germany, is part of the European subpopulation of $P$. ramorum, and is of the A1 mating type, while isolate Pr-52 originated from rhododendron in California and is of A2 mating type. Certain differences have been reported to exist between the United States and European $P$. ramorum populations, $(3,16)$ including higher levels of virulence and growth over a wider range of temperatures for European isolates. However, we did not observe major differences between the two isolates used in this study in virulence on the range of hosts tested.

Inoculum density studies showed that $P$. ramorum could infect susceptible hosts bearberry and 'Minuet' mountain laurel with inoculum concentrations ranging from 100 to 5,000 sporangia per $\mathrm{ml}$. The response curve for infection as a function of sporangia concentration showed the same linear slope, and thus, a similar response to increasing inoculum density for both hosts. The minimum spore concentration allowing $P$. ramorum infection to occur was 100 sporangia per $\mathrm{ml}$ with both hosts. Determination of this lower limit of inoculum concentration for $P$. ramorum infection of ornamental hosts may prove useful in efforts of APHIS to develop pest risk assessment (PRA) models for spread of $P$. ramorum to new areas. Furthermore, since infection was shown to be possible with only 100 sporangia per $\mathrm{ml}$, the concentration we chose $(5,000$ sporangia per $\mathrm{ml}$ ) for routine screening could thus be considered moderate or high and the screening test considered fairly stringent.

Results of chlamydospore quantification studies showed that, in general, susceptible hosts were able to support formation of more chlamydospores in their tissue compared with hosts deemed to be more resistant. An exception was $G$. procumbens (wintergreen). Although appearing to have low susceptibility in the screening tests (mean adjusted percent leaf area infected of 2.1) it supported the largest number of chlamydospores in tissue of any of the hosts tested. This result is significant because it indicates that certain hosts that may sustain very low infection levels can still serve as potent reservoirs of inoculum for $P$. ramorum. Were this phenomenon widespread, it could result in mildly infected hosts producing large amounts of chlamydospore inoculum, which might contribute to epidemics in new areas where these hosts were transported. However, several other hosts in the resistant range, such as highbush blueberry and cranberry, produced virtually no chlamydospores, indicating that host physiology affects the propensity for chlamydospores to form in the tissue. The physiological factors conditioning high or low chlamydospore production in different plant host species should be investigated further. California bay laurel sustained the second highest number of chlamydospores of any host tested, indicating its propensity to support 
inoculum production that may contribute to SOD epidemics in areas where it is present along with susceptible oak species.

Our results, documenting the susceptibility of numerous ornamental hosts to $P$. ramorum, will be useful to the states already involved in $P$. ramorum surveys (8) and to those that will be involved in future surveys initiated in response to the recent spread of the pathogen to the eastern United States (32). Knowledge of host reactions under greenhouse conditions may help in choosing target hosts for surveying in nursery settings. Surveyors could focus on finding $P$. ramorum in association with such highly susceptible hosts such as $K$. latifolia, which grows widely in the eastern United States naturally and as a valued landscape plant. Whether the results from our containment greenhouse studies will be paralleled by natural occurrence is unknown. However, some of the hosts we have reported as susceptible, $K$. latifolia and Pieris japonica, have since our work began, been reported as $P$. ramorum hosts under natural conditions (26,33; J. Jones, personal communication). Thus, our results may be useful in predicting which additional plant species may prove to serve as natural hosts for $P$. ramorum. In the future, additional ericaceous species as well as members of additional plant families should be tested for their susceptibility to $P$. ramorum to determine the likelihood of their serving as natural hosts for the pathogen.

\section{ACKNOWLEDGMENTS}

We are very grateful to D. Rizzo and S. Werres for providing the isolates of $P$. ramorum used in this study. A special thanks is owed to D. Rizzo and J. Davidson for providing essential help in learning to work with $P$. ramorum. We thank S. Oak, U.S. Forest Service, Asheville, NC and S. Gordon of Kinney Azalea Gardens, Kingston, RI for assistance in choosing and providing host plants for this study. We thank L. Lamari for considerable help in using the ASSESS software program. We also thank Bell Nursery, Historyland Nursery, Yoder Brothers, Oregon Azaleas, and K. Kosta of the California Department of Food and Agriculture for donating plant material for these studies. We owe much thanks to D. Berner for in-depth guidance on statistical analysis of our data and J. Phillips for input on experimental design. We thank C. Cavin for much assistance in the containment greenhouse and D. Koogle for assistance in plant maintenance.

\section{LITERATURE CITED}

1. Anonymous. 2002. Commission decision (2002/757/EC) of 19 September 2002 on provisional emergency phytosanitary measures to prevent the introduction into and the spread within the community of Phytophthora ramorum Werres, De Cock \& Man in't Veld sp. nov. Off. J. Eur. Communities, 2002-09-20, L. 252,3739 .

2. Anonymous. 2003. National Pest Alert. Sudden Oak Death, Phytophthora ramorum. USDA-CSREES National IPM Centers.
3. Brasier, C. 2003. Sudden oak death: Phytophthora ramorum exhibits transatlantic differences. Mycol. Res. 107:258-259.

4. Brummitt, R. K. 1992. Vascular Plant Families and Genera. Royal Botanic Garden, Kew, UK.

5. California Department of Food And Agriculture. 2003. Section 301.92 Phytophthora ramorum. Pages 224.1-224.5 in: CDFA Plant Quarantine Manual.

6. Canadian Food Inspection Agency. 2003. Phytosanitary Requirements to Prevent the Entry of Phytophthora ramorum Associated with Sudden Oak Death into Canada. Directive D01-01. September 25, 2003.

7. Caten, C. C., and Jinks, J. L. 1968. Spontaneous variability of single isolates of Phytophthora infestans. I. Cultural variation. Can. J. Bot. 46:329-348.

8. Cooperative Agriculture Pest Survey Program. 2002. Sudden Oak Death 2002/2003 Pilot National Survey. Center for Environmental and Regulatory Systems (CERIS). On-line Publication. Purdue University, West Lafayette, IN.

9. Coyier, D. L., and Roane, M. K. eds. 1986. Compendium of Rhododendron and Azalea Diseases. The American Phytopathological Society, St. Paul, MN.

10. Davidian, H. H. 1982-c1995. The Rhododendron Species. Vol. I-IV. Timber Press, Portland, OR.

11. Davidson, J. M., Garbelotto, M., Koike, S. T., and Rizzo, D. M. 2002. First report of Phytophthora ramorum on Douglas-fir in California. Plant Dis. 86:1274.

12. Davidson, J. M., Rizzo, D. M., Garbelotto, M., Tjosvold, S., and Slaughter, G. W. 2002. Phytophthora ramorum and sudden oak death in California: II. Transmission and survival. Pages 741-749 in: Proc. Fifth Symp. Oak Woodlands: Oaks in California's Changing Landscape: 2001. Gen. Tech. Rep. PSW-GTR184. R. B. Standiford, D. McCreary, and K. L. Purcell, eds. Pacific Southwest Research Station, Forest Service, U.S. Department of Agriculture, Albany, CA.

13. Davidson, J. M., Werres, S., Garbelotto, M., Hansen, E. M., and Rizzo, D. M. 2003. Sudden oak death and associated diseases caused by Phytophthora ramorum. Online-publication. doi:10,1094/PHP-2003-0707-01-DG. Plant Health Progress.

14. De Merlier, D., Chandelier, A., and Cavelier, M. 2003. First report of Phytophthora ramorum on Viburnum bodnantense in Belgium. Plant Dis. 87:203.

15. Englander, L., and Tooley, P. 2003. Plant Hosts in the Nursery Industry-PLANTS MOVE! Sudden Oak Death On-line publication. doi: 10.1094/SOD-2003-LE. The American Phytopathological Society, St. Paul, MN.

16. Garbelotto, M., Rizzo, D. M., Hayden, K., Meija-Chang, M., Davidson, J. M., and Tjosvold, S. 2002. Phytophthora ramorum and sudden oak death in California: III. Preliminary studies in pathogen genetics. Pages 765774 in: Proc. Fifth Symp. Oak Woodlands: Oaks in California's changing landscape. 2001. Gen. Tech. Rep. PSW-GTR-184. R. B. Standiford, D. McCreary, and K. L. Purcell, eds. Pacific Southwest Research Station, Forest Service, U.S. Department of Agriculture Albany, CA.

17. Goheen, E. M., Hansen, E. M., Kanaskie, A., McWilliams, M. G., Osterbauer, N., and Sutton, W. 2002. Sudden oak death caused by Phytophthora ramorum in Oregon. Plant Dis. 86:441.
18. Hansen, E. M., Reeser, P. W., Sutton, W. Winton, L. M., and Osterbauer, N. 2003. First report of A1 mating type of Phytophthora ramorum in North America. Plant Dis. $87: 1267$.

19. Inman, A. J., Townend, V. C., Barnes, A. V., Lane, C. R., Hughes, K. J. D., Griffin, R. L. and Eales, S. J. 2003. First report of Ramorum dieback (Phytophthora ramorum) on Pieris in England. New Dis. Rep. 7. On-line publication. Br. Soc. Plant Pathol.

20. Jeffers, S. N., and Martin, S. B. 1986. Comparison of two media selective for Phy tophthora and Pythium species. Plant Dis. 70:1038-1043.

21. Jones, J. 2004. APHIS List of Plants Regulated and Associated with Phytophthora ramorum. On-line publication.USDA-APHIS.

22. Lamari, L. 2002. ASSESS: Image Analysis Software for Plant Disease Quantification. The American Phytopathological Society, St. Paul, $\mathrm{MN}$.

23. Lane, C. R., Beales, P. A., Hughes, K. J. D. Griffin, R. L., Munro, D., Brasier, C. M., and Webber, J. F. 2003. First outbreak of Phytophthora ramorum in England on Viburnum tinus. Plant Pathol. 52:414.

24. Maloney, P. E., Rizzo, D. M., Koike, S. T., Harnik, T. Y., and Garbelotto, M. 2002. First report of Phytophthora ramorum on coast redwood in California. Plant Dis. 86:1274

25. Moralejo, E., and Werres, S. 2002. First report of Phytophthora ramorum on Rhododendron sp. in Spain. Plant Dis. 86:1052.

26. Parke, J. L., Linderman, R. G., Osterbauer, N. K., and Griesbach, J. A. 2004. Detection of Phytophthora ramorum blight in Oregon nurseries and completion of Koch's postulates on Pieris, Rhododendron, Viburnum, and Camellia. Plant Dis. 88:87.

27. "Phytophthora ramorum." Code of Federal Regulations. 2003 ed. Title 7, Pt. 301.92 Pages142-148.

28. Rizzo, D. M., Garbelotto, M., Davidson, J. M., Slaughter, G. W., and Koike, S. T. 2002. Phytophthora ramorum as the cause of extensive mortality of Quercus spp. and Lithocarpus densiflorus in California. Plant Dis. 86:205214.

29. Rizzo, D. M., Garbelotto, M., Davidson, J. M., Slaughter, G. W., and Koike, S. T. 2002. Phytophthora ramorum and Sudden Oak Death in California: I. Host Relationships. Pages 733740 in: Proc. Fifth Symp. Oak Woodlands: Oaks in California's changing landscape. 2001. Gen. Tech. Rep. PSW-GTR-184. R. B Standiford, D. McCreary, and K. L. Purcell, eds. Pacific Southwest Research Station, Forest Service, U. S. Department of Agriculture, Albany, CA.

30. Salley, H. E., and Greer, H. E. 1992. Rhododendron Hybrids. Timber Press, Portland, OR.

31. SAS Institute. 1999. SAS/STAT User's Guide: Version 8, Vol. 1, 2, and 3. SAS Publishing, Cary, NC

32. Stokstad, E. 2004. Nurseries may have shipped sudden oak death pathogen nationwide. Science 303:1959.

33. Werres, S., and De Merlier, D. 2003. First detection of Phytophthora ramorum mating type A2 in Europe. Plant Dis. 87:1266.

34. Werres, S., Marwitz, R., Man In't Veld, W. A., DeCock, A. W. A. M., Bonants, P. J. M., De Weerdt, M., Themann, K., Ilieva, E., and Baayen, R. P. 2001. Phytophthora ramorum sp. nov., a new pathogen on Rhododendron and Viburnum. Mycol. Res. 105:1155-1165. 